\title{
CENTRAL NERVOUS SYSTEM METASTASES FROM BREAST CARCINOMA
}

\author{
A CLINICAL AND LABORATORIAL STUDY IN 47 PATIENTS
}

\author{
ALUIZIO B.B. MACHADO*, ALEXANDRE A.C. MACHADO**, \\ JOSÉ ALEXANDRE M. BARBUTO***, RICARDO M. DE OLIVEIRA****
}

\begin{abstract}
In this retrospective study, 47 patients with clinical diagnosis of central nervous system metastases of breast cancer were evaluated by computerized tomography (CT), magnetic resonance imaging (MRI) and cerebrospinal fluid (CSF) examination. The patients were divided in 2 groups: 1, without leptomeningeal neoplasm and 2, with leptomeningeal neoplasm. In the group 2, the time interval between the primary disease and the central nervous system metastasis as well as the survival time were shorter than in group 1 (40 and 4.3 months in group 2 versus 57 and 10 months respectively, in group 1). In both groups the most common neurological symptoms and signs were intracranial hypertension and motor deficits. The most sensitive diagnostic methods were CT and MRI in group 1, and the CSF examination in group 2. The use of the tumor markers CEA and CA15.3 in the routine examination of CSF showed promising results, mainly in leptomeningeal forms.
\end{abstract}

KEY WORDS: central nervous system metastasis, breast cancer, cerebrospinal fluid, tumor markers.

\begin{abstract}
Metástases do sistema nervoso central por câncer de mama: estudo clínico-laboratorial em 47 pacientes
RESUMO - Neste estudo retrospectivo, 47 pacientes com diagnóstico clínico de metástases do sistema nervoso por câncer de mama foram avaliados por tomografia computadorizada (TC), ressonância nuclear magnética (RNM) e por exames do líquido cefalorraqueano (LCR). Os pacientes foram divididos em 2 grupos: 1, sem neoplasia leptomeníngea e 2, com neoplasia leptomeníngea. No grupo 2 o intervalo de tempo entre a doença primária e o comprometimento do sistema nervoso e o tempo de sobrevida foram menores do que no grupo 1 (40 e 4,3 meses no grupo 2 versus 57 e 10 meses respectivamente, no grupo 1). Os sinais e sintomas neurológicos mais frequentes foram hipertensão intracraniana e déficits motores. Os exames mais sensíveis para o diagnóstico foram a TC e RNM no grupo 1 e o exame do LCR no grupo 2. O uso dos marcadores CEA e CA-15.3 na rotina do LCR mostrou resultados promissores, particularmente nas formas leptomeníngeas.
\end{abstract}

PALAVRAS-CHAVE: metástases no sistema nervoso central, câncer de mama, líquido cefalorraqueano, marcadores tumorais.

Autopsy studies show that central nervous system (CNS) metastasis of breast cancer occur in nearly $30 \%$ of the patients but only $10 \%$ are diagnosed or suspected clinically before death ${ }^{1,2}$. Recent epidemiological data indicate that the incidence of CNS metastasis has been increasing in the last two decades; this could be explained by the increased survival of the breast cancer patients nowadays ${ }^{3,4}$. The clinical presentation of these patients is pleomorphic, depending on the localization of the lesions, meningeal involvement and paraneoplastic syndromes, as well as on therapeutic complications $s^{2,5}$. Specific and sensitive diagnostic tools, both clinical and laboratorial, must be familiar to the neuro-oncologist.

Departamento de Patologia Clínica e Hemoterapia do Hospital A.C. Camargo (Serviço de Neuropatologia Clínica): *Médico Titular, Mestre em Neurologia, FMUSP; **Médico Estagiário; ***Médico Titular, Professor Doutor do Departamento de Imunologia, ICB-USP; ****Médico Titular, Diretor do Departamento. Aceite: 9-janeiro-1998.

Dr. Aluízio B.B. Machado - Departamento de Patologia Clínica e Hemoterapia, Hospital A.C. Camargo - Rua Antonio Prudente 211 - 01509-010 São Paulo SP - Brasil. FAX (011) 270 0896. E-mail: acmach@ uol.com.br 
Among the approaches that have been allowing the early diagnosis of CNS cancer metastasis, a fundamental condition for effective treatment, are the neuro-imaging techniques (NI) and the cerebrospinal fluid examination (CSF) ${ }^{6-9}$. NI can be diagnostic in 25 to $90 \%$ of the CNS metastasis, depending on the pattern of invasion, with clearly better results when there is parenchymal involvement, than when only leptomeningeal involvement occurs ${ }^{10,11}$. Of the solid tumors causing meningeal involvement, those from breast are the most frequent ${ }^{12,13}$. The CSF cytomorphological study, due to its high specificity, is considered the gold standard to confirm the presence of leptomeningeal neoplasms and, depending on the site and on the number of samplings, presents sensitivity of up to $90 \% \%^{2,4,14,15}$. The presence of tumor markers in the CSF has been object of clinical research, but its validity has been hampered by the limited methodological standardization and number of patients studied ${ }^{11}$.

In the present retrospective study, clinical and laboratorial data, including CSF levels of tumor markers, of patients diagnosed with CNS involvement by breast cancer are presented.

\section{PATIENTS AND METHODS}

Clinical and laboratorial data of 136 patients with a diagnosis of breast cancer between August 1991 and July 1997 were analyzed. All patients were submitted to NI and CSF examinations and the presence of CNS metastasis was confirmed by either method or both in 47 patients (34\%). These patients were divided in two groups: group 1 included patients whose NI was positive for CNS involvement but CSF cyto-oncological study was negative (no leptomeningeal disease - NMD), and group 2 included patients with malignant cells in the CSF, configuring the diagnosis of leptomeningeal neoplasms (MD).

The NI techniques used varied among patients, depending on clinical indications, and included cerebral computerized tomography (CT) (40 cases), myelotomography ( 9 cases), nuclear magnetic resonance of the brain ( 5 cases) and of the spinal cord (2 cases).

CSF samples were analyzed for cell count, cytomorphology, total protein, glucose, and lactate dehydrogenase levels. Some samples were analyzed for the levels of carcinoembryonic antigen (CEA) and CA15.3. All samples were analyzed by the methods used routinely in the laboratory: cytomorphology of cells cytocentrifuged and stained by the Leishman technique and immunochemical analysis by automated methods (turbidimetry, colorimetry and immunochemoluminescence). Reference values were established in the laboratory.

\section{RESULTS}

Patient age, time interval between primary tumor diagnosis and CNS metastasis, survival after CNS involvement and pathological diagnosis are presented in Table 1. Table 2 shows the most frequent signs and symptoms, obtained during the neurological examination, grouped according to previous suggestions ${ }^{2,16}$. Data obtained by NI are shown in Table 3.

The main alterations observed in the first sample of CSF from 47 patients are presented in Table 4. Table 5 summarizes the CSF data from the 25 patients with leptomeningeal disease.

\section{DISCUSSION}

This study analyzes data from CNS metastasis of mammary neoplasms, including clinical and laboratorial findings in patients without meningeal involvement (group 1) and in patients with meningeal disease (group 2).

The mean age of group 1 and group 2 was 53 and 50 years respectively, data that are comparable to other reports ${ }^{2,14}$. Mean time between primary tumor diagnosis and the CNS invasion was 49 months, also similar to the reported $\mathrm{data}^{2}$. In the group 2, as a result of the more aggressive behavior of meningeal neoplasms, this interval was shorter. The mean survival after CNS involvement was 7 months, longer than has been described earlier ${ }^{2,4,14}$, and probably reflecting the improvement in diagnostic and therapeutic approaches for these conditions. Again, consistent with the biological behavior of meningeal diseases, mean survival in group 2 patients was significantly shorter than in group 1 (four months in group 2 versus ten months in group 1). 
Table 1. Clinical and pathological data from 47 patients with confirmed diagnosis of CNS metastasis, both nonmeningeal (NMD) and meningeal $(M D)$.

\begin{tabular}{lcccc}
\hline & & Group 1 (NMD) & Group 2 (MD) & Total \\
\hline Number of patients & & 22 & 25 & 47 \\
\hline Age & Mean & 53 & 50 & 51 \\
& Median & 54 & 49 & $29-68$ \\
\hline & Range & $37-65$ & $29-68$ & 45 \\
\hline Interval between & $\mathrm{N}$ & 21 & 24 & 49 \\
PT and CNS metastasis & Mean & 57 & 41 & 34 \\
(months) & Median & 32 & 35 & $5-220$ \\
\hline \multirow{2}{*}{ Survival range (months) } & Range & $7-220$ & $5-180$ & 30 \\
\cline { 2 - 5 } & N & 14 & 16 & 7 \\
& Mean & 10 & 4 & 2.5 \\
& Median & 4 & 2 & $1-38$ \\
\hline PT diagnosis & Metastasis & $1-38$ & $1-19$ & 44 \\
& DC & 21 & 23 & 2 \\
\hline
\end{tabular}

$\mathrm{N}$, number of evaluable patients; PT, primary tumor; DC, ductal carcinoma; LC lobular carcinoma; C, carcinoma.

Table 2. Frequency (\%) of signs and symptoms in 47 patients with CNS metastasis of breast cancer, both with non-meningeal (NMD) and meningeal diseases $(M D)$.

\begin{tabular}{llcc}
\hline & & Group 1 (NMD) & Group 2 (MD) \\
\hline \multirow{2}{*}{ Symptoms } & Vertigo, nausea, vomiting & 41 & 36 \\
& Headache & 36 & 32 \\
& Motor deficit & 23 & 36 \\
& Mental alterations & 18 & 20 \\
& Sphincter control alterations & 5 & 20 \\
& Diplopy & 14 & 8 \\
& Nucal rigidity & 0 & 20 \\
& Convulsions & 14 & 4 \\
& & & 16 \\
& Crural paraparesis & 14 & 4 \\
& Mental alterations & 18 & 12 \\
& VII cranial nerve & 9 & 16 \\
& Areflexy & 5 & 8 \\
& V cranial nerve & 0 & 8 \\
\hline
\end{tabular}

The neurological examination data coincide with those of the literature ${ }^{2,11,16}$. Intracranial hypertension symptoms were the dominant clinical manifestation. These included vertigo, nausea and vomiting, headache and eventually mental alterations, diplopy and convulsions. Focal symptoms, like motor deficit caused by central and peripheral nervous system lesions, as well as nucal rigidity, were more commonly found in patients with leptomeningeal disease. Mental alterations were more frequent in those patients presenting brain nodules, while in those with leptomeningeal disease, 
Table 3. Neuroimaging data from 38 patients with CNS metastasis of breast cancer.

\begin{tabular}{llccc}
\hline & & Group I (NMD) & Grupo 2 (MD) & Total \\
\hline \multirow{2}{*}{ Number of metastasis } & One & $13(59 \%)$ & $7(44 \%)$ & $20(53 \%)$ \\
& More than one & $9(41 \%)$ & $9(56 \%)$ & $18(47 \%)$ \\
Metastasis site & Brain & $19(79 \%)$ & $14(74 \%)$ & $33(77 \%)$ \\
& Meninges & - & $3(16 \%)$ & $6(14 \%)$ \\
& Spinal cord & $5(21 \%)$ & $1(5 \%)$ & $3(7 \%)$ \\
& Cranial nerves & - & $1(5 \%)$ & $1(2 \%)$ \\
\hline
\end{tabular}

Table 4. Alterations in the first CSF sample obtained from 47 patients with CNS metastasis of breast cancer.

\begin{tabular}{|c|c|c|c|c|c|c|}
\hline & $\begin{array}{l}\text { Group } 1 \\
\text { (MD) }\end{array}$ & $\mathrm{n}$ & $\begin{array}{l}\text { Group } 2 \\
\text { (NMD) }\end{array}$ & $\mathrm{n}$ & Total & $\mathrm{n}$ \\
\hline Total cell count $>4 / \mathrm{uL}$ & $1(5 \%)$ & 22 & $13(52 \%)$ & 25 & $14(39 \%)$ & 47 \\
\hline Total protein $>40 \mathrm{mg} / \mathrm{dL}$ & $6(27 \%)$ & 22 & $19(76 \%)$ & 25 & $25(53 \%)$ & 47 \\
\hline Glucose $<50 \mathrm{mg} / \mathrm{dL}$ & $2(9 \%)$ & 22 & $7(28 \%)$ & 25 & $9(19 \%)$ & 47 \\
\hline $\mathrm{LDH}>26 \mathrm{U} / \mathrm{L}$ & $1(5 \%)$ & 22 & $13(52 \%)$ & 25 & $14(30 \%)$ & 47 \\
\hline $\mathrm{CEA}>1.5 \mathrm{ng} / \mathrm{mL}$ & $0(0 \%)$ & 4 & $8(62 \%)$ & 13 & $8(47 \%)$ & 17 \\
\hline $\mathrm{CA}-15.3>1 \mathrm{U} / \mathrm{mL}$ & $2(20 \%)$ & 10 & $11(69 \%)$ & 16 & $13(50 \%)$ & 26 \\
\hline
\end{tabular}

n, number of samples analyzed.

Table 5. Summary of the CSF findings from 25 patients with leptomeningeal metastasis of breast cancer.

\begin{tabular}{lccccc}
\hline & $\mathrm{N}$ & mean & median & range & reference values \\
\hline Total cell count $(/ \mathrm{uL})$ & 25 & 19 & 4.3 & $0.3-156$ & $<4$ \\
Neoplastic cells $(/ 1000)$ & 25 & 1250 & 105 & $1.4-14820$ & 0 \\
Total protein $(\mathrm{mg} / \mathrm{dL})$ & 25 & 97 & 51 & $11-447$ & $<40$ \\
Glucose $(\mathrm{mg} / \mathrm{dL})$ & 25 & 68 & 63 & $14-170$ & $50-90$ \\
LDH $(\mathrm{U} / \mathrm{L})$ & 25 & 73 & 27 & $0-706$ & $<26$ \\
CEA $(\mathrm{ng} / \mathrm{mL})$ & 13 & 2 & 1.9 & $0.1-9.1$ & $<1.5$ \\
CA-15.3 $(\mathrm{U} / \mathrm{mL})$ & 16 & 57.8 & 2.3 & $0.4-789$ & $<1$ \\
\hline
\end{tabular}

$\mathrm{N}$, number of patients.

focal signs predominated, due to the multiplicity of lesions involving brain, spinal cord and cranial nerves (III, V and VII).

In the present study, NI presented at least one alteration in $81 \%$ of the patients and, in $47 \%$ of the patients, more than one metastasis was detected. In $77 \%$ of the altered exams, the metastasis were localized in the brain, while in only $7 \%$ of the patients did the NI show leptomeningeal involvement. This observation confirms the low sensitivity of NI for the detection of these lesions. Furthermore, among the patients with a confirmed diagnosis of meningeal disease by CSF examination, only $16 \%$ presented meningeal alterations detected by NI. However, non-meningeal 
involvement was a frequent finding in patients with meningeal neoplasms (64\%), indicating its common association with other metastasis. Considering all patients, the most common images observed were nodular $(84 \%)$, followed by abnormal enhancing of parenchyma and/or meninges $(18 \%)$ and ventricular dilatation $(5 \%)$.

Cytomorphology of CSF was used to define the diagnosis of meningeal disease, according to established procedures ${ }^{4,14}$. Total cell count was abnormal in only one patient of group 1 (NMD) but in 13 patients of group 2 (MD). In this group, $53 \%$ had a positive oncotic cytology already at the first CSF sample. High protein, low glucose and high LDH levels were more frequent in group 2 patients, again in accordance with published data ${ }^{4,6,14}$. Tumor markers, CEA and CA-15.3 levels were introduced in our routine evaluation in order to establish their prevalence and usefulness. Using previously suggested criteria ${ }^{17}$ and our laboratory standardization, tumor markers were elevated in CSF of $47 \%$ (CEA) and 50\% (CA-15.3) of all the patients, with patients in group 2 presenting alterations in a higher proportion $(62 \%$ and $69 \%)$. In the 25 CSF samples with positive oncotic cytology, the immunochemical analysis provided mean and median above the reference values in all parameters with exception of the glucose levels.

These results are similar to most of the published data and confirm that in breast cancer patients with signs and symptoms of neurological disease the diagnostic approach should associate neuroimaging with CSF examination ${ }^{3,12,18}$. The introduction of CEA and CA-15.3 analysis in the CSF work-up showed promising results, particularly as a diagnostic aid in leptomeningeal neoplasms.

\section{REFERENCES}

1. Lamovec J, Zidar A. Association of leptomeningeal carcinomatosis in carcinoma of the breast with infiltrating lobular carcinoma: an autopsy study. Arch Pathol Lab Med 1991;115:507-510.

2. Tsukada Y, Fouad A, Pickren JW, Lane WW. Central nervous system metastasis from breast carcinoma: autopsy study. Cancer 1983;52:2349-2354.

3. Kamby C, Soerensen P. Characteristics of patients with short and long survivals after detection of intracranial metastases from brest cancer. J Neurol Oncol 1988;6:37-45.

4. Yap HY, Yap BS, Tashima CK, DiStefano A, Blumenschein R. Meningeal carcinomatosis in breast cancer. Cancer 1978;42:283-286.

5. Yung WKA, Sawaya R, Curran Jr WJ, Fuller GN. Intracranial metastatic central nervous system tumors. In Levin VA (ed): Cancer in the nervous system. New York: Churchill Livingstone, 1996:243-258.

6. Bach F, Bjerregaard B, Sölétormos G, Bach FW, Horn T. Diagnostic value of cerebrospinal fluid cytology in comparison with tumor marker activity in central nervous system metastases secondary to breast cancer. Cancer 1993;72:2376-2382.

7. Bach F, Sölétormos G, Dombernowsky P. Tissue polypeptide antigen activity in cerebrospinal fluid: a marker of central nervous system metastases of breast cancer. J Natl Cancer Inst 1991;83:779-784.

8. Sze G, Milano E, Johnson C, Heier L. Detection of brain metastases: comparison of contrast-enhanced MR with unenhanced MR and enhanced CT. Am J Neuroradiol 1990;11:785-791.

9. Watanabe M, Tanaka R, Takeda N. Correlation of MRI and clinical features in meningeal carcinomatosis. Neuroradiology 1993;35:512-515.

10. Black P, Wen P. Clinical, imaging and laboratory diagnosis of brain tumors. In Kaye AH, Laws Jr ER (eds): Brain tumors. New York: Churchill Livingstone, 1995:191-214.

11. Wen PY, Fine HA. Leptomeningeal metastases. In Black PM, Loeffler JS (eds); Cancer of the nervous system. Massachusetts: Blackwell, 1997:288-309.

12. Grossman SA, Moynihan TJ. Neoplastic meningitis. Neurol Clin 1991;3:843-856.

13. Wasserstrom WR, Glass JP, Posner JB. Diagnosis and treatment of leptomeningeal metastases from solid tumors: experience with 90 patients. Cancer 1982;49:759-772.

14. Jayson GC, Howell A, Harris M, Morgenstern G, Chang J, Ryder WD. Carcinomatous meningitis in patients with breast cancer: an aggressive disease variant. Cancer 1994;74:3135-3141.

15. Wen PY. Diagnosis and management of brain tumors. In Black PM, Loeffler JS (eds): Cancer of the nervous system. Massachusetts: Blackwell, 1997:106-127.

16. Chamberlain MC, Friedman HS. Leptomeningeal metastases. In Levin VA (ed): Cancer in the nervous system. New York: Churchill Livingstone, 1996:281-290.

17. Yap BS, Yap HY, Fritsche HA, Blumenschein G, Bodey GP. CSF carcinoembryonic antigen in meningeal carcinomatosis from breast cancer. JAMA, 1980;244:1601-1603.

18. Patchell RA. Brain metastases. In Black PM, Loeffler JS (eds). Cancer of the nervous system. Massachusetts: Blackwell, 1997:653-663. 